\title{
geosciences
}

ISSN 2076-3263

www.mdpi.com/journal/geosciences

Article

\section{Examining Local Climate Variability in the Late Pennsylvanian Through Paleosols: An Example from the Lower Conemaugh Group of Southeastern Ohio, USA}

\author{
Nicole D. Dzenowski and Daniel I. Hembree* \\ Department of Geological Sciences, Ohio University, 316 Clippinger Laboratories, Athens, OH 45701, \\ USA; E-Mail: ndzenowski@gmail.com
}

* Author to whom correspondence should be addressed; E-Mail: hembree@ohio.edu;

Tel.: +1-740-597-1495; Fax: +1-740-593-0486.

Received: 14 September 2012; in revised form: 18 October 2012/ Accepted: 29 October 2012/

Published: 1 November 2012

\begin{abstract}
Three temporally close stratigraphic sections were excavated in Glenshaw Formation of Athens County, Ohio. The described units are Upper Pennsylvanian (Gzhelian, 305-302 Ma) and located in the distal portion of the Appalachian foreland basin. Mudstone units interpreted as paleosols were identified across all three sections. Detailed field and micromorphological studies lead to the recognition of two separate paleosols within the profile. The profile consists of a composite paleosol composed of two cumulative paleosols. The lower paleosol is interpreted as a calcic Vertisol which formed in a seasonally dry environment whereas the upper paleosol is interpreted as a gleyed Inceptisol which formed in a seasonally wet environment. The change in paleosol types is the result of increased precipitation which led to saturation of the soil and surface ponding. Pedogenic carbonate nodules are a common feature throughout the entire profile as are stress cutans. A coalesced carbonate horizon (Bk) was observed approximate $120 \mathrm{~cm}$ from the top of the profile in all three sections. This carbonate horizon formed in the Vertisol and later served as a barrier which limited the downward movement of surface water. This limited the gleization of the bottom portion of the overprinted Vertisol resulting in a diffuse boundary with the overlying Inceptisol and producing a composite paleosol.
\end{abstract}

Keywords: soils; terrestrial; continental; paleoclimate; paleopedology 


\section{Introduction}

The stratigraphy of the northern portion of the Appalachian basin records climatic shifts from tropical ever-wet to sub-tropical conditions marked by moderate to strong seasonality often with significant dry periods during the deposition of the Late Pennsylvanian Conemaugh Group [1-5]. Paleosols have the potential to be excellent tools in the reconstructions of terrestrial paleoenvironments and paleoclimate due to the fact that they formed in direct exposure to climatic and related environmental conditions [6]. Topography, drainage conditions, and variability in the type and distribution of plants and animals, however, all have the potential to affect soil formation. Small-scale, detailed studies are therefore necessary in order to accurately reconstruct and fully understand continental paleoenvironments due to the variable nature of terrestrial landscapes.

Paleopedology in conjunction with ichnology takes into account the external, environmental forces acting upon the soil, including plants and other soil organisms, allowing for improved interpretation of the overall paleoenvironment [6-8]. Various features within a paleosol such as nodules, slickensides, fractures, or mottles can allude to the seasonality of an environment $[9,10]$. The types of nodules present, horizon depth, as well as color and chemical variations within mottles allow for a more accurate interpretation of moisture conditions as well as the occurrence of or length of wet versus dry seasons and mean annual precipitation [6,9,11]. Fossils are extremely useful in understanding the paleoenvironmental, paleoecological, and paleoclimatic conditions but taphonomic processes limit body fossil preservation overall [5]. Since body fossil preservation is rare within these types of environments, the utilization of trace fossils is especially important in environmental interpretations. Paleosols preserve the activity of plants and animals, via ichnofossils, below and above the soil surface which represents soil biotas' direct response to environmental and climatic conditions.

This study uses data obtained from the general stratigraphy as well as the paleopedology and ichnology of three spatially close sections within the Late Pennsylvanian (Gzhelian) Glenshaw Formation (Conemaugh Group) of southeastern Ohio to reconstruct regional scale paleoclimatic conditions which affected the local development and evolution of soils and terrestrial landscapes.

\section{Geologic Setting}

The Appalachian basin is a foreland basin that formed in response to thrusting and sedimentation during multiple orogenic events including the Acadian, Taconic, and the Alleghenian orogenies [12]. The Appalachian basin during the Middle to Late Pennsylvanian was located in the tropics at a paleolatitude of approximately $5-10^{\circ} \mathrm{S}[13-15]$. During this time the Appalachian basin was flanked on the northwest by the Cincinnatian Arch and on the southeast by the Appalachian Highlands [15]. Deposition in the Appalachian basin was controlled by glacio-eustatic sea level fluctuations and tectonics as well as changing climatic conditions which caused shifting deltaic environments responsible for the thick sandstone deposits found throughout the basin [1,16-20]. Exposure in southeastern Ohio within the distal portion of the Appalachian basin was due to sedimentation and overthrusting during the final Alleghenian orogeny [21].

Three major Late Pennsylvanian stratigraphic groups are present in southeastern Ohio: the Allegheny Group, the Conemaugh Group, and the Monongahela Group [22]. The Conemaugh Group is exposed in southeastern Ohio, southwestern Pennsylvania, western Maryland, eastern Kentucky, and The Glenshaw 
Formation (Gzhelian, 305-302 Ma) is approximately 60-100 m thick and made up predominantly of sandstone and mudstone with thin limestone and coal beds that accumulated in alluvial, deltaic, and shallow-marine environments [23]. Within southeastern Ohio, the Glenshaw Formation is approximately $98 \mathrm{~m}$ thick [24]. The more inland nature of the Glenshaw Formation in southeast Ohio makes it an ideal location for studying Pennsylvanian paleosols due to the thicker paleosol sequences and thinner marine sequences than are present further into the Appalachian Basin [19].

Red and green paleosols are common within the Glenshaw Formation at the base of the transgressive and regressive sequences and are typically distinct due to their easily weathered appearance [2,5,12,23]. A recent study by Hembree and Nadon [5] found that paleosols of the Glenshaw Formation within southeastern Ohio consists of red to green blocky vertic Calcisols interpreted as Vertisols. The Glenshaw Formation paleosols contain carbonate nodules as well as iron nodules towards the tops of the profile indicating a climatic shift from a dry environment to one with increased precipitation [5]. In general within the Appalachian basin, the Glenshaw Formation is characterized by a facies sequence of paleosols capped by coal, marine or lacustrine limestone, and shale indicative of well-drained soil conditions followed by a drowning event, marking a sequence boundary [23].

\section{Methods}

Three $20 \mathrm{~m}$ sections within the Ames and Harlem members of Sturgeon [22] were excavated just below the Ames Limestone at the Highway 33/Stimson Avenue exit in Athens, Ohio (39¹9'22.01" N, $82^{\circ} 05^{\prime} 18.42^{\prime \prime}$ W) (Figures 1 and 2a). General stratigraphic sections were completed for each trench noting major changes in lithology (Figure 2b). Two paleosols were identified 4.1-4.6 m below the top of each section and directly below a shale unit. The paleosols were described, sampled at $20 \mathrm{~cm}$ intervals, and detailed stratigraphic columns were made for each profile (Figures 3-5). Samples were collected after excavating 25-50 cm of sediment and weathered material to expose fresh rock. Paleosol and mottle color were determined using dry samples and a rock color chart [25]. In the field, the lithology, texture, and preserved horizons of the paleosols were documented as well as the type, abundance, and distribution of nodules and ichnofossils. These features were used to aid in paleosol classification using the descriptive system of Mack et al. [26] as well as in the interpretation of the paleosols using the U.S. Soil Taxonomy system [27].

Fifty-one total thin sections were prepared by a commercial laboratory (Texas Petrographic Services, Inc., Houston, TX, USA) from the samples collected every $20 \mathrm{~cm}$ as well as from large nodules and samples that showed distinct pedogenic features such as rhizoliths, mottles, or gley; 19 thin sections were obtained from section one, 16 from section two, and 16 from section three. Four sizes of thin sections were produced including $2.5 \times 5.0 \mathrm{~cm}(\mathrm{n}=13), 4.0 \times 7.5 \mathrm{~cm}(\mathrm{n}=8), 5.0 \times 7.5 \mathrm{~cm}(\mathrm{n}=13)$, and $2.5 \times 7.5 \mathrm{~cm}(\mathrm{n}=17)$. The thin sections were analyzed using a Motic BA300 (Motic, Xiamen, China) polarizing microscope and photographed with a MotiCam 3000 (Motic, Xiamen, China). The pedogenic microfabrics were classified according methods outlined by Brewer [28]. Thin sections were also used in determining the average grain size of paleosols, to determine if illuviated clays were present within the paleosols, and to observe rhizoliths and other biogenic structures not visible in hand samples. Size, type, abundance, and orientation of mottles and rhizoliths were recorded and used in soil classification, interpretation of drainage conditions, and paleoenvironmental conditions. Field observations were used 
in conjunction with the micromorphology of the paleosols in the paleoenvironmental, paleoclimatic, and paleoecological reconstructions.

Figure 1. (a) Location of Athens, County within Ohio. Figure after Hembree and Nadon [5]; (b) Map of Athens County where the study took place. The orange dot marks the location of the field site within Athens County; (c) Stratigraphic column of the Conemaugh Group within southeastern Ohio after Sturgeon [22].
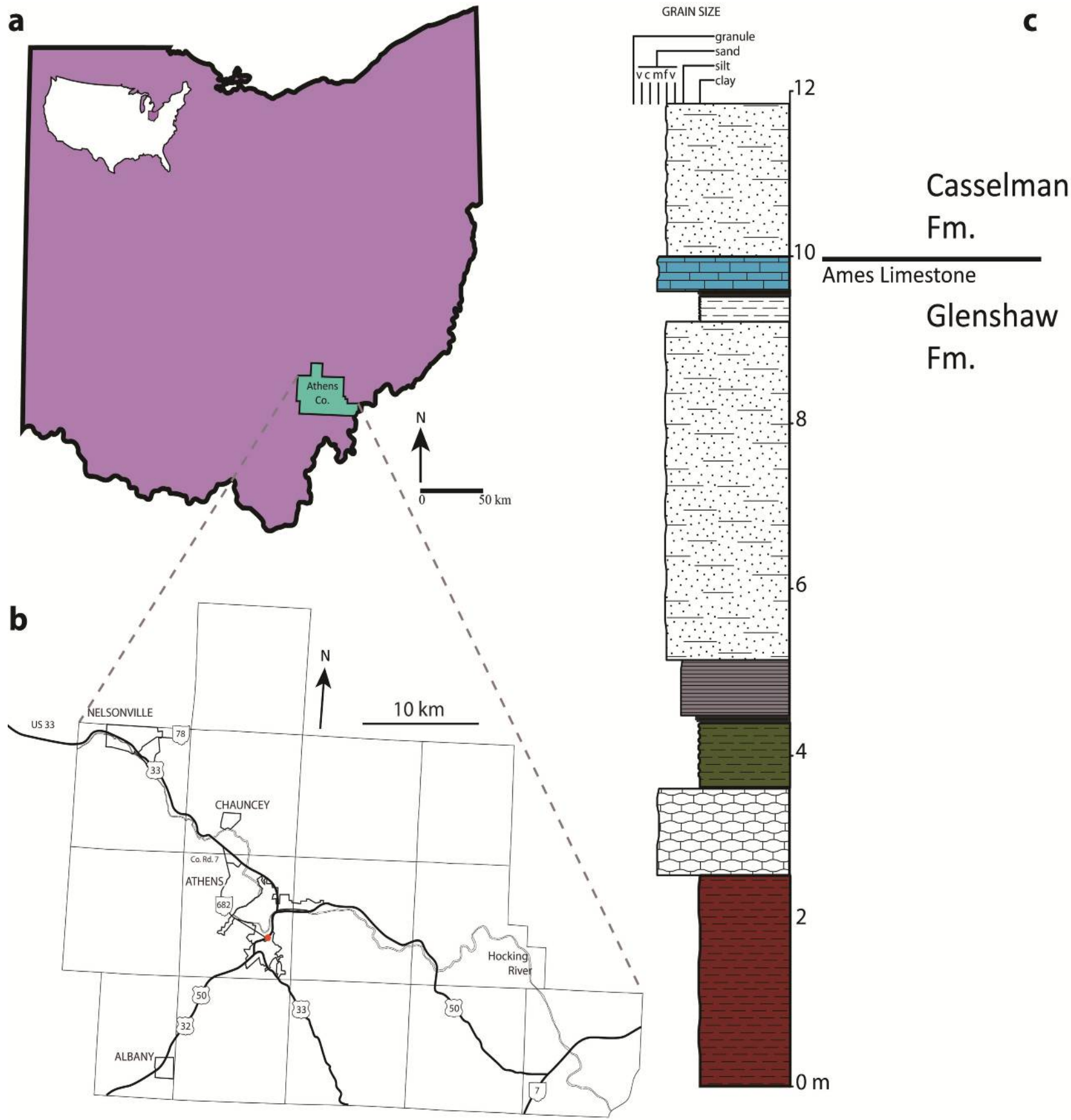
Figure 2. Field location and general stratigraphic columns of the three sections excavated. (a) Field location at Highway 33/Stimson Avenue exit in Athens County, OH, USA. The arrows point to the excavated sections; (b) General stratigraphic columns of the three section which were excavated below the Ames limestone.

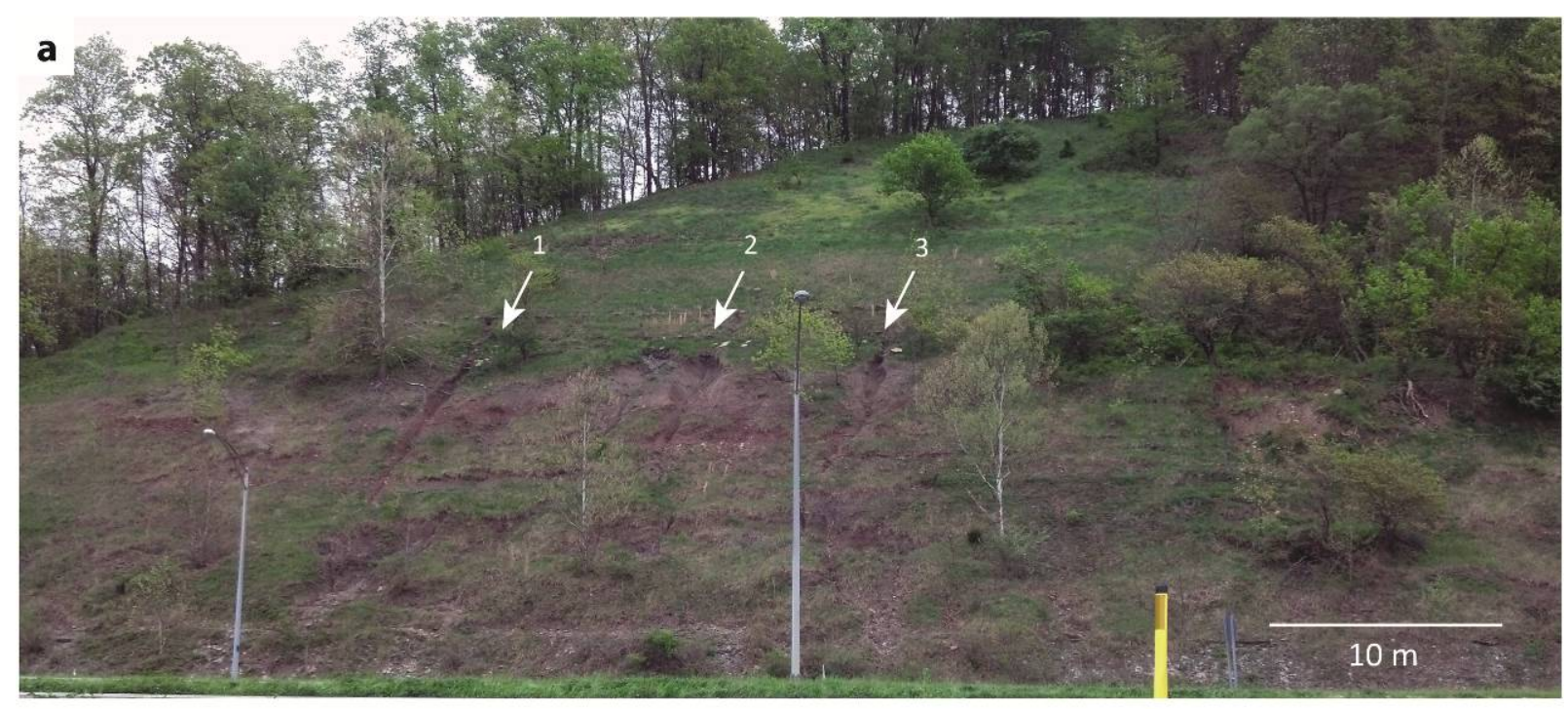

b

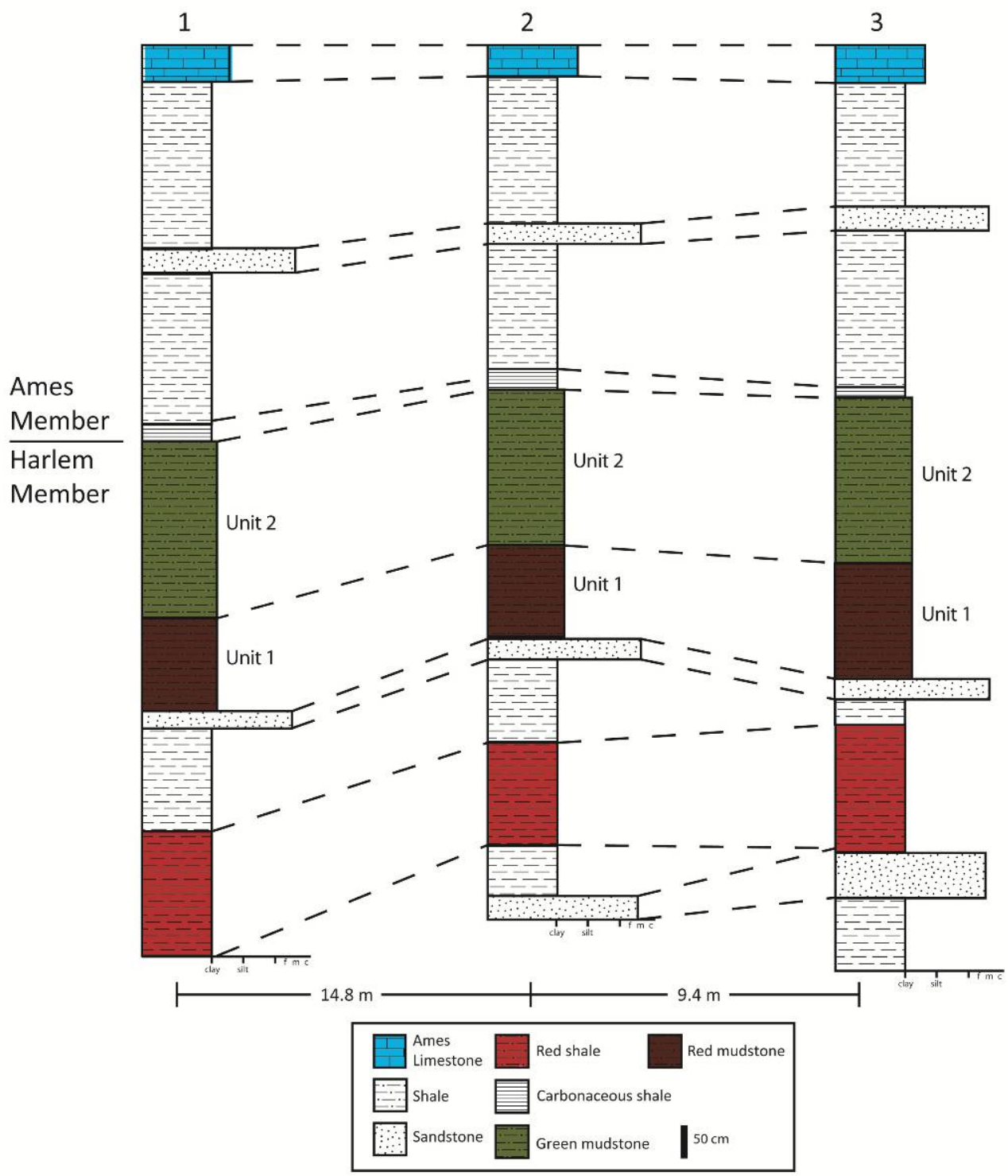


Figure 3. Detailed stratigraphic column and micromorphological features of the interpreted paleosols present in Section 1. (a) Detailed section of Units 1 and 2; (b) Root trace with a fine organic core, 20-40 cm; (c) Porphyroskelic fabric and fractures, 80-100 cm; (d) Fabric within gradational contact, 160-180 cm; (e) Rounded, clay aggregate, 200-220 cm; (f) Iron rich, subangular peds, $320-340 \mathrm{~cm}$.

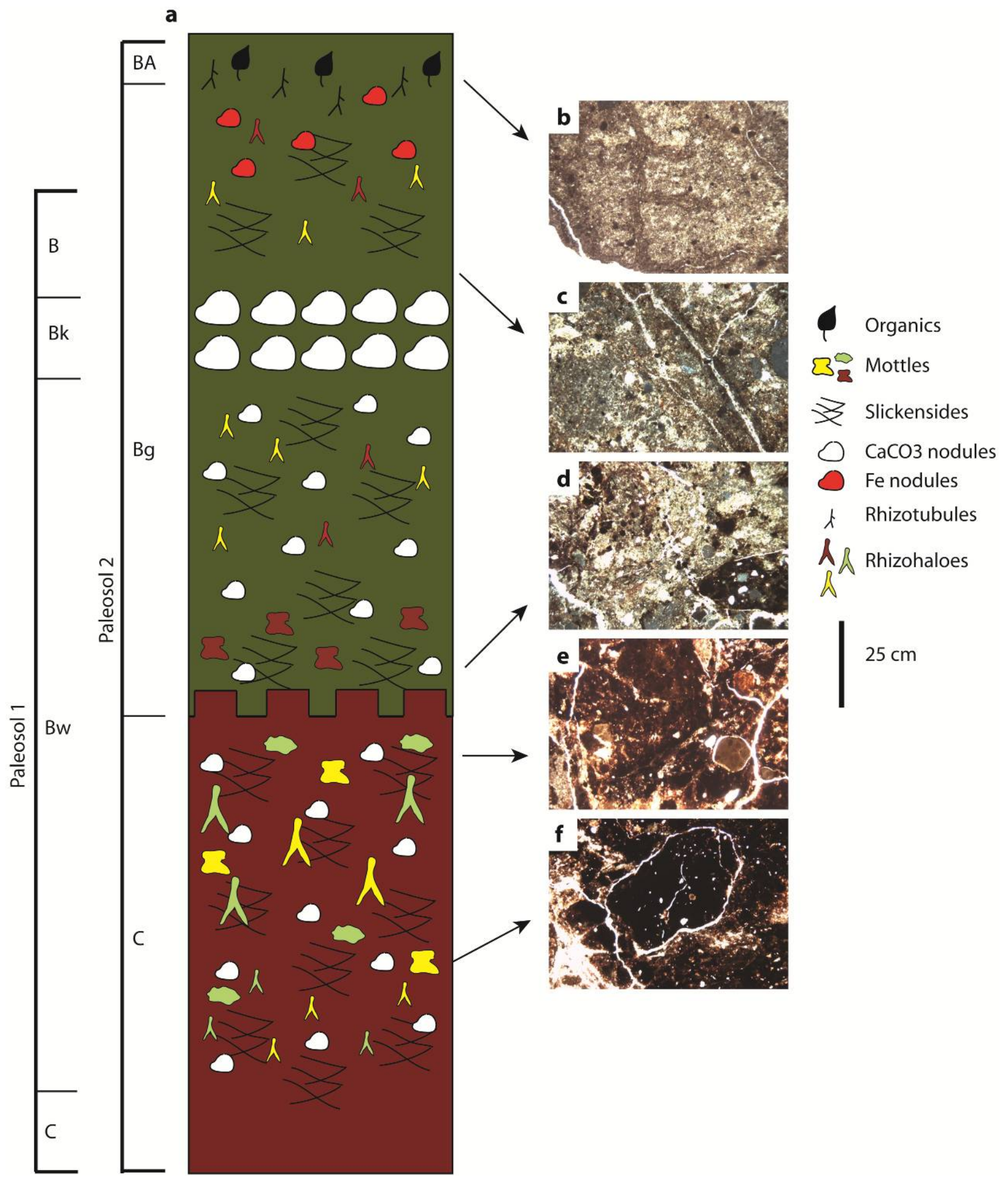


Figure 4. Detailed stratigraphic column and micromorphological features of the interpreted paleosols present in Section 2. (a) Detailed section of Units 1 and 2; (b) Carbonate nodule with secondary sparry calcite, $0-20 \mathrm{~cm}$; (c) Coalescing carbonate nodules within the Bk horizon, 120-140 cm; (d) Root trace and porphyroskelic fabric, 140-160 cm; (e) Clay aggregates showing the insepic microfabric, 180-200 cm; (f) Carbonate nodules, 260-280 cm.

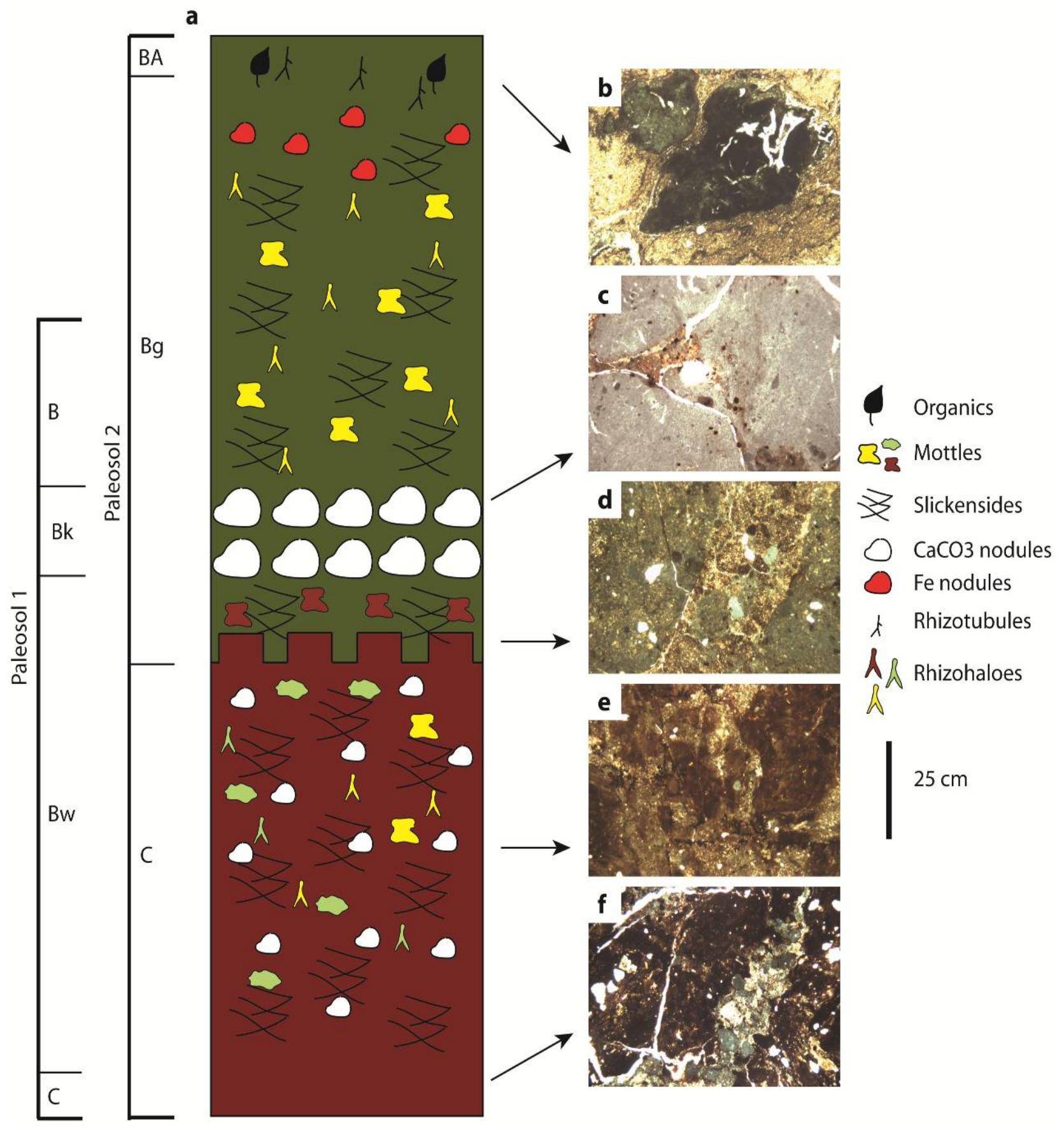


Figure 5. Detailed stratigraphic column and micromorphological features of the interpreted paleosols present in Section 3. (a) Detailed section of Units 1 and 2; (b) Carbonate nodule at 0-20 cm; (c) Carbonate nodule and shell fragment within carbonate horizon at 80-100 cm; (d) Illuviated clay surrounding fractures, 160-180 cm; (e) Porphyroskelic fabric, 220-240 cm; (f) Carbonate nodules within a fracture, $260-280 \mathrm{~cm}$.

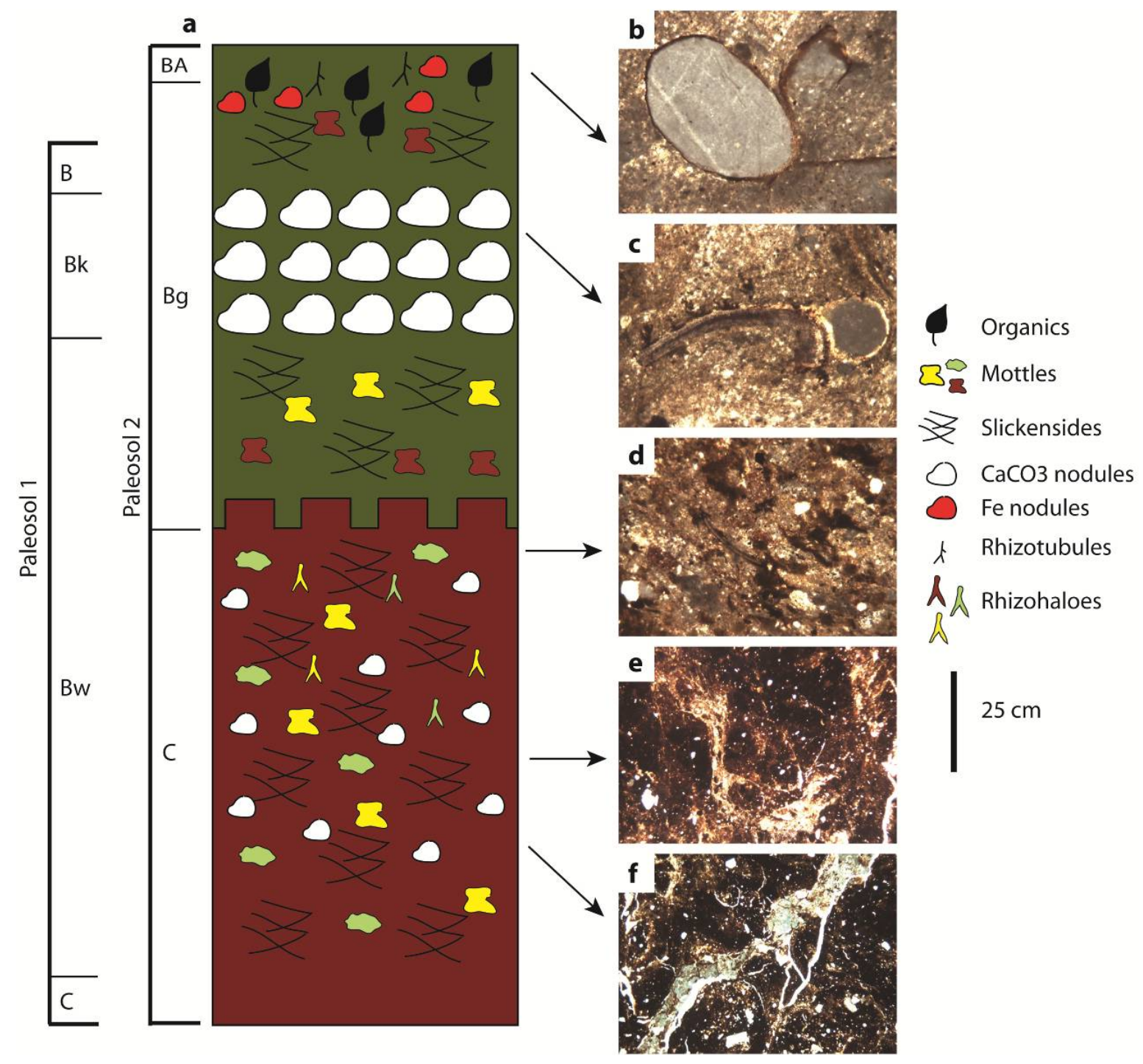

\section{Paleopedology}

\subsection{Description}

Two stacked, laterally continuous paleosol profiles are present in all three sections and are overlain by a shale unit with an abrupt contact. The combined paleosol sequence is 3.0-3.8 $\mathrm{m}$ thick and consists of a 160-230 cm thick, red-brown (5YR 3/4) mudstone (Unit 1) overlain by a 110-200 cm thick, green-grey (5Y 4/2) mudstone (Unit 2). The contact between Units 1 and 2 is gradational. The red-brown coloration of Unit 1 becomes less red and more variegated towards the contact with Unit 2. Both Units 1 and 2 are massive with an angular blocky texture. Cutans and slickensides are present on the individual angular blocks throughout both units. While typically small, a large-scale slickenside surface $(25 \times 16 \mathrm{~cm})$ was exposed in Section 2 within Unit 1 (Figure 6a). Sub-rounded carbonate nodules appear evenly dispersed 
throughout Unit 1. A concentrated area of carbonate nodules, 20-60 cm thick, occurs $60-180 \mathrm{~cm}$ below the top of Unit 2 (Figure 6e). Carbonate and iron nodules, 2-6 cm in diameter, are dispersed non-uniformly within the upper $25-30 \mathrm{~cm}$ of Unit 2 . Fine organic matter as well as fine $(0.5-1 \mathrm{~mm}$ wide), vertically oriented, tapering rhizoliths occur within the upper portion of Unit 2. Tapering and branching yellow and red mottles are present throughout Unit 2 (Figure 6b) while green-grey and yellow mottles are more common in Unit 1 (Figure 6c,d). Unit 1 within Section 1 contains abundant, downward tapering green-grey and yellow mottles $(0.5-1.0 \mathrm{~cm}$ in diameter) which begin approximately $20 \mathrm{~cm}$ down from the top of the contact with Unit 2. These large mottles continue downward for $100 \mathrm{~cm}$ where they are replaced by finer $(0.1-0.5 \mathrm{~cm})$ green-grey and yellow mottles. Unit 1 in Sections 2 and 3 contain similar yellow and green-grey, downward tapering mottles, but these are generally at a much finer scale $(0.5-2.0 \mathrm{~mm})$ and significantly less abundant.

Figure 6. Pedogenic features observed in the field. (a) Large, exposed slickenside surface $(16 \times 25 \mathrm{~cm})$ in Section 1 within Unit 1; (b) Green-grey color (gley) of the mudstone of Unit 2 in Section 1; (c) Angular blocky texture of Unit 1 in Section 1 with green and yellow mottles; (d) Drab colored mottle present in the upper portion of Unit 1 in Section 1; (e) Horizon of carbonate nodules weathering out of Unit 2 in Section 2.
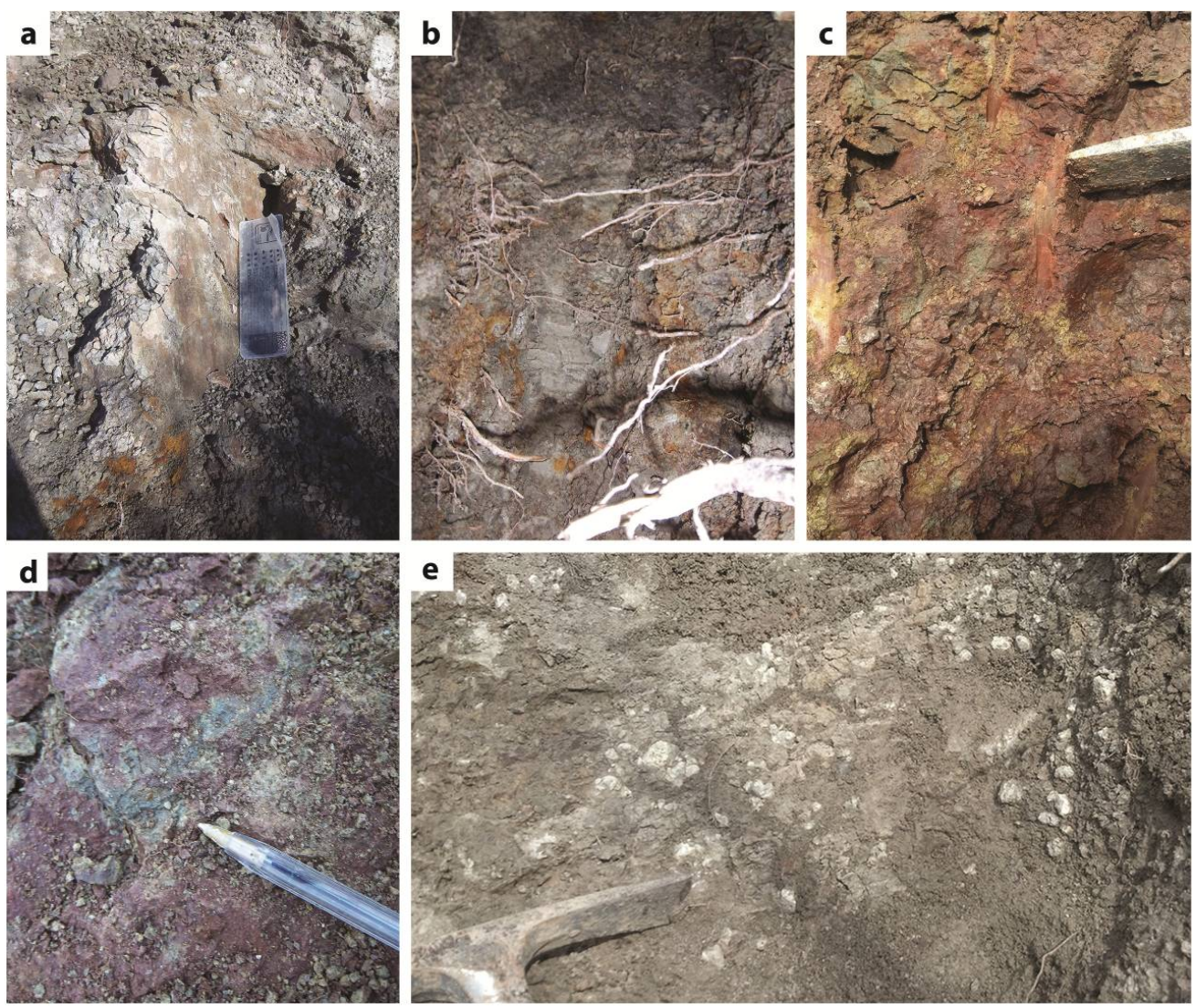

\section{Micromorphology}

\subsection{Description}

The micromorphology of the paleosols is marked by a porphyroskelic microfabric with a typically insepic to vosepic plasmic fabric. Carbonate nodules, which are tuberose in shape and surrounded by 
oriented clay, are abundant throughout all of the thin sections but become more abundant toward the top of Unit 2. Many of the nodules have evidence of root traces which were secondarily filled in with sparry calcite (Figure 7a). Finely crystalline calcite throughout the fabric becomes more common while carbonate nodules begin to decrease in size $(0.1-0.3 \mathrm{~mm})$ towards the bottom of Unit 1 .

Figure 7. Paleosol features observed within thin section. (a) Calcite nodule within Unit 1 with a root trace secondarily filled with sparry calcite; (b) Rounded accumulation of illuviated clay within Unit 1; (c) Organic particle within the gleyed portion Unit 2; (d) Sub-angular to angular blocky peds of Unit 1 seen throughout both units; (e) Millimeter-scale fractures lined with illuviated clay within Unit 1. One fracture (at arrow) formed around a root trace and later filled in with sparry calcite; (f) Example of mottles seen in Unit 1; (g) Clay-lined burrow found within Unit 2; (h) Complete ostracode found in the upper portion of Unit 2.
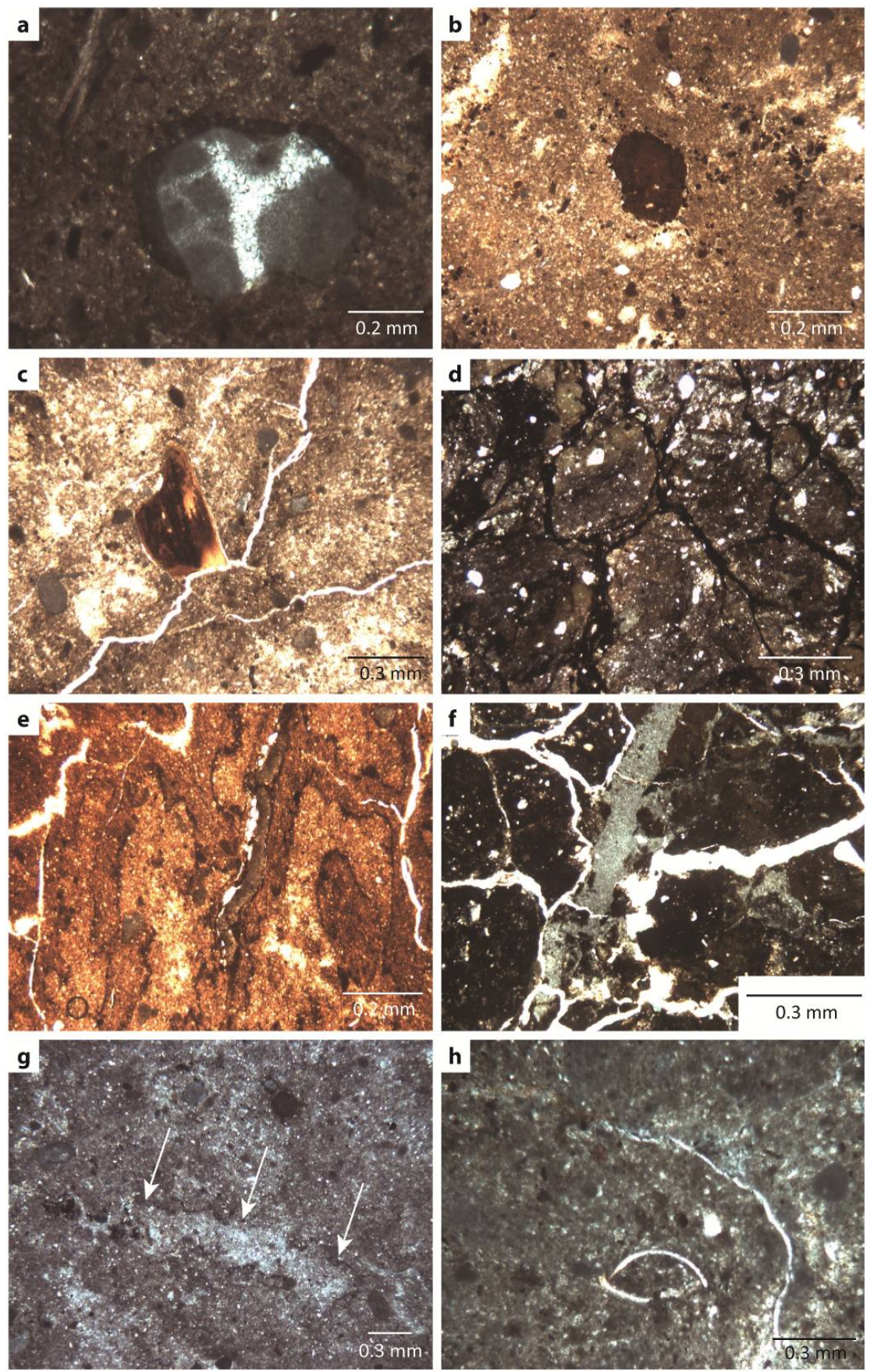
Argillan cutans were observed throughout Units 1 and 2 as well as rounded accumulations of clay (Figure 7b). Clay-lined rhizoliths containing organic cores were observed in thin sections of Unit 2 as well as rare isolated organic particles $(0.6 \times 1.0 \mathrm{~mm})$ (Figure $7 \mathrm{c})$. Subangular to angular blocky peds surrounded by bright clay fabrics were observed throughout the thin sections (Figure 7d). Fracture networks were common within the thin sections of Unit 1 and were lined by high birefringence clay and rarely filled with coarsely crystalline calcite (Figure 7e). A few clay-lined and drab-colored mottles were observed in thin section as well as unlined mottles (Figure $7 \mathrm{f})$. One small $(0.2-0.3 \mathrm{~mm})$ burrow was present within Unit 2 (Figure $7 \mathrm{~g}$ ). The burrow was outlined with illuviated clay and possessed a compacted lining. Ostracode valves were observed in thin sections of the upper portion of Unit 2 within each section (Figure $7 \mathrm{~h}$ ). Abundant and weathered pyrite was also observed in the top of each section in Unit 2 down to approximately $120 \mathrm{~cm}$.

\section{Discussion}

\subsection{Paleosol Interpretation}

Given their physical properties including the presence of horizons, peds, cutans, rhizoliths, pedogenic carbonate nodules, and illuviated clay, Units 1 and 2 are interpreted as paleosols. Two different episodes of paleosol development can be interpreted from the distinct macro- and micromorphological features present within each unit. Therefore, the two mudstone units represent two different, stacked paleosol profiles (Figures 3-5); however, each unit does not represent a single paleosol. Instead the two paleosols together comprise a composite paleosol, formed under relatively steady conditions of sedimentation and bioturbation but with two distinct, overlapping profiles produced by a notable change in the climatic conditions. Each individual paleosol may be considered cumulative as a result of the overthickened B horizons, suggesting that there was a negligible amount of erosion occurring throughout the formation of the individual soils as well as steady and nearly equal levels of sedimentation and pedogenesis [11]. As a result, as sediment was steadily deposited on the landscape, it was immediately incorporated into the active soils.

Paleosol 1, which includes both Units 1 and 2, consists of a B horizon, a Bk horizon, an overthickened $\mathrm{Bw}$ horizon, and an underlying $\mathrm{C}$ horizon which contains remnants of unaltered parent material, the underlying sandstone (Figures 3-5,8a). The dominant pedogenic features of Paleosol 1 are the abundant slickenside surfaces as well as decimeter-scale fractures or desiccation cracks which are a common feature within modern Vertisols or more generally vertic soils [10,27,29,30]. These cracks and fractures form due to the soil's clay content. During wet periods, clays within the soil swell causing different units of soil matrix to expand then shift and slide past each other [29-31]. Stress cutans or slickensides are evidence of this movement [10]. Once a decrease in precipitation occurs and the dry season begins, the clays dry and contract, forming open cracks which are filled with illuviated clay or other sediment [29-31]. Sub-angular to angular blocky peds are present within this portion of the paleosol, likely caused by these cycles of shrinking and swelling [29-31]. The uneven distribution of rhizoliths in Paleosol 1 is consistent with the sparse vegetation typically seen in vertic soils and represents variability in vegetation across the landscape [32]. The rarity of burrows found may be due to extremely pedoturbated nature of the paleosol; burrows that were present have likely been overprinted resulting in decreased burrow visibility [33]. 
Figure 8. Stratigraphic columns showing the effects of the changing climate on formation of Paleosols 1 and 2. (a) Vertisol (Paleosol 1) formation occurring in a seasonally dry climate; (b) Increased precipitation leads to gleization of the underlying Vertisol and the formation of a gleyed Inceptisol (Paleosol 2); (c) Sea level rise results in cessation of soil formation and the deposition of the overlying carbonaceous shale.

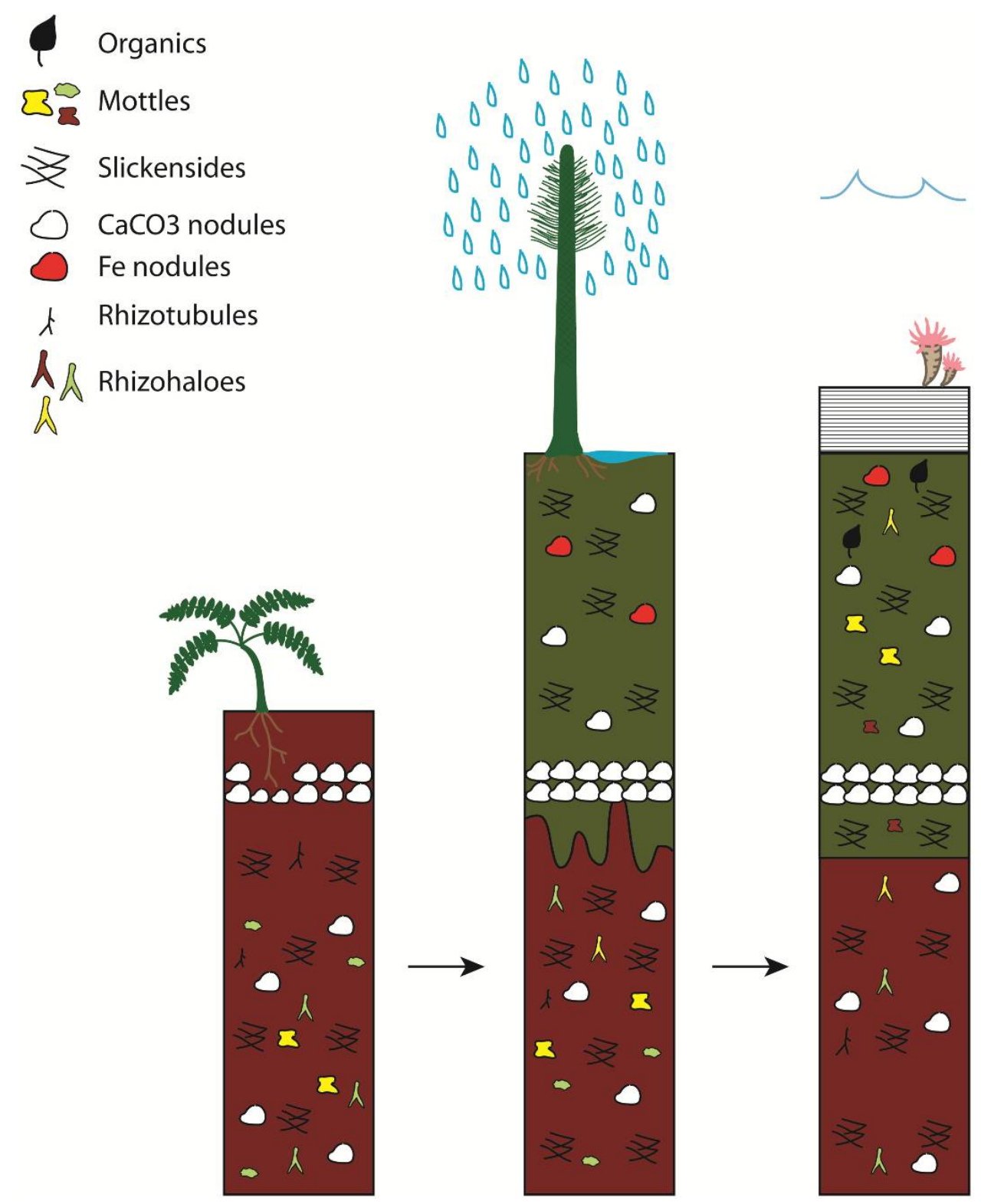

This is suggested by the presence of abundant mottling in hand sample and thin section. Due to the lack of distinct morphological features, however, it is difficult to distinguish whether theses biogenic traces were produced by roots or soil animals. Both mottles and rhizoliths become less abundant towards the bottom of Paleosol 1 in conjunction with the beginning of the $\mathrm{C}$ horizon.

The red color of the lower portion (Unit1) of Paleosol 1 is indicative of oxidizing conditions [9]. This coloration, which is caused by the high ferric iron content along with the presence of illuviated clays, is representative of moderately to well-drained conditions [9]. The upper 50-150 cm of Paleosol 1 is represented by Unit 2 and is dominated by a green-grey color, but with background mottles of red, brown, and yellow (Figures 3-5). This indicates that the green-gray color, typically suggestive of reducing 
conditions, is overprinting a previously oxidized paleosol [9]. Argillan cutans observed in hand samples along with insepic microfabrics and clay aggregates within thin sections from both Units 1 and 2 also indicate a well-drained soil with clays produced in the A and $\mathrm{E}$ horizon being washed down deeper into the profile [9]. Dispersed carbonate nodules are a common feature along with abundant, fine-grained calcite present throughout the paleosols microfabric. The carbonate horizon (Bk) consisting of large coalesced nodules present within Unit 2 was also produced within Paleosol 1. The Bk horizon also indicates a well-drained paleosol within a seasonal environment. In order for carbonate nodules to form, periods of precipitation are necessary to wash the calcium carbonate down through the profile [10,34-36]. A dry period is then necessary for the evaporation of the water which allows the calcite to precipitate out and coalesce [34-36]. The dispersed carbonate nodules occurring below the Bk horizon which steadily decrease in size towards the bottom of the paleosol were likely produced during an interval of steady sedimentation and soil aggradation resulting in an overthickened Bw horizon; this is typical of cumulative paleosols [11]. The development of an overlying Bk horizon suggests that sedimentation slowed to produce a single horizon of carbonate nodules at the depth of wetting [9,10,34-36].

The dominant vertic features and abundant carbonate nodules and calcite lead to the classification of the lower paleosol as a calcic Vertisol [26] and it is interpreted as a Vertisol [27]. Vertisols typically take $10^{2}-10^{4}$ years to form; the presence of a Stage 3 carbonate horizon indicates a more mature paleosol which likely took over $10^{3}$ years for formation [9,37].

Paleosol 2, which includes Unit 2, is characterized by a $\mathrm{Bg}$ horizon that overprints Paleosol 1 (Figures 3-5). Paleosol 1 is therefore interpreted as the parent material of Paleosol 2. Gley overprinting and the gradational contact between the two paleosols makes the horizon separating the two soils difficult to locate. Paleosol 2 contains drab, low chroma (green-grey) colors indicative of ferrous iron suggesting a reducing environment in which the formerly well-drained soil (Paleosol 1) became waterlogged (Figure 8b) [4]. Rare organic particles were observed within thin section and rhizohaloes in both hand sample and thin section had organic cores approximately $25 \%$ of the time. The preservation of organics is consistent with reducing conditions in soils produced where microbes deplete the soil water of its oxygen which in turn limits the activity of aerobic microorganisms that would otherwise decompose buried vegetation and other organic material $[9,10]$. The pyrite present in thin section is also a feature common of gleyed paleosols due to the production of reduced iron minerals such as pyrite [38]. Likewise, the reduced iron nodules present at the top of the profile are common in gleyed paleosols and are typically produced in response to increased soil saturation [9,10]. Fracture patterns are still common throughout this portion of the profile as were slickensides, therefore shrinking and swelling cycles were likely still occurring even during this period of increased soil saturation and gleization. The continuation of shrink-swell structures up the profile indicates that seasonal conditions were still ongoing. This combination of properties suggests that while the soil was not always saturated, surface ponding did occur which is further suggested by the preservation of ostracodes in the Bg horizon of Paleosol 2, a common organism found in waterlogged soils [9]. Ostracode valves were notably present within mottles and interpreted root traces indicating they were washed down into the paleosol profile along with percolating water.

Reducing conditions are the dominant soil-forming features for Paleosol 2 leading to its classification as a vertic Gleysol [26] and its interpretation as an Inceptisol, more specifically an Aquept [27]. This paleosol is interpreted to have taken over $10^{-2}$ years to form $[9,39]$. 


\subsection{Paleoclimatic Significance}

Vertic features have the potential to be formed in various climates if a sufficient volume of expandable clays are present within the soil [10,27]. However, it is unlikely for a pedogenic calcite horizon to form in an environment with a high mean annual precipitation [40-42]. The combination of vertic and calcic features, therefore, suggests that Paleosol 1 formed in a semiarid to subhumid environment with a seasonal distribution of precipitation and good drainage conditions. Gleyed soils, similar to Vertisols, can form in a number of climates with extended periods of soil saturation from the influence of groundwater or the ponding of surface water, but are often indicative of humid environments with high mean annual precipitation $[11,32,41]$. The vertic features observed within both paleosols as well as the overprinting gleization of the $\mathrm{Bw}$ and Bk horizons of the pre-existing Paleosol 1 which occurred in Paleosol 2 are features typically produced in response to high seasonal precipitation [41,43]. A shift from a seasonal climate with long dry periods and low mean annual precipitation to a still seasonal but wetter climate with increased mean annual precipitation best explains the gradual change from a well-drained, well-oxygenated soil to a reduced, increasingly saturated soil (Figure 8).

This change in climate resulted in an increased amount of water entering the soil profile (Figure $8 b$ ). The relict carbonate horizon would have provided a barrier for much of the water, creating a poorly drained profile and effectively waterlogging the soil above over time especially during the wet season $[9,10]$. Continued sedimentation along with bioturbation during the climate shift maintained steady rates of aggradation and pedogenesis which is indicated by the preservation of organics and sparse root traces that represent the patchy vegetation inhabiting the changing soil. Over time, a transgressive event occurred, ending soil formation and resulting in the deposition of the overlying carbonaceous shale (Figure 8c).

\section{Conclusions}

The Late Pennsylvanian Glenshaw Formation of Athens County, Ohio contains a composite paleosol that consists of two distinct, cumulative paleosols formed as a result a climatic shift from a semiarid, seasonal environment with extended dry periods to a subhumid, seasonal environment with extended wet periods. A transition from an oxidized paleosol (Paleosol 1) with abundant calcite nodules to a reduced paleosol (Paleosol 2) with preserved organics characterizes the complete profile. The basal red paleosol, Paleosol 1, is interpreted as a Vertisol that was covered with sparse vegetation and formed in a region with lengthy dry seasons. The upper green-grey paleosol, Paleosol 2, which overprints the upper portion of Paleosol 1, is interpreted as an Inceptisol (Aquept) that formed due to an increase in mean annual precipitation that created longer periods of soil saturation and the accumulation of standing water on the soil surface. Both soils contain evidence of being intermittently well-drained with illuviated clays present in thin section as well as clay skins in hand sample. The presence of a carbonate horizon in the underlying Vertisol contributed to the poorly drained conditions present within the Inceptisol. The clay content present within the entire profile and the slickensides present on the mudstone blocks in hand sample provide further proof that the environment remained seasonal but that a shift from a long dry season to a long wet season occurred. The patchy distribution of rhizoliths as well as their variability in abundance and size from Section 1 to Sections 2 and 3 
indicate the overall paucity of vegetation that distinguished the landscape, but show that the size and quantity of flora did vary over short distances (10 s of meters).

This study provides further proof that information obtained from the physical properties of paleosols both in hand sample and thin section is essential to the interpretation of the paleoenvironmental, paleoecological, and paleoclimatic conditions which can affect soil formation. Landscape variability and changing climatic conditions can occur over a short spatial and temporal scale, making localized paleopedological studies the most accurate tool in interpreting local paleoenvironmental and paleoclimatic conditions.

\section{Acknowledgments}

We would like to thank two anonymous reviewers for their helpful comments and suggestions. We would also like to thank Logan Scally and Dustin Horvath for their assistance in the field. Funding was provided by the Ohio University Department of Geology Alumni Graduate Research Grant and the SEPM Ed Picou Fellowship Grant for Graduate Studies in the Earth Sciences.

\section{References}

1. Cecil, C.B.; Stanton, R.W.; Neuzil, S.G.; Dulong, F.T.; Ruppert, L.F.; Pierce, B.S. Paleoclimate controls on Late Paleozoic sedimentation and peat formation in the central Appalachian basin. Int. J. Coal Geol. 1985, 5, 195-230.

2. Joeckel, R.M. Paleosols below the Ames marine unit (Upper Pennsylvanian, Conemaugh Group) in the Appalachian basin, U.S.A.: Variability on an ancient depositional landscape. J. Sediment. Res. 1995, 65, 393-407.

3. DiMichele, W.A.; Pfefferkorn, H.W.; Gastaldo, R.A. Response of Late Carboniferous and Early Permian plant communities to climate change. Annu. Rev. Earth Planet. Sci. 2001, 29, 461-487.

4. DiMichele, W.A.; Cecil, C.B.; Montañez, I.P.; Falcon-Lang, H.J. Cyclic changes in Pennsylvanian paleoclimate and effects on floristic dynamics in tropical Pangaea. Int. J. Coal Geol. 2010, 83, 329-344.

5. Hembree, D.I.; Nadon, G.C. A paleopedologic and ichnologic perspective of the terrestrial Pennsylvanian landscape in the distal Appalachian Basin, U.S.A. Palaeogeog. Palaeoclimatol. Palaeoecol. 2011, 312, 138-166.

6. Sheldon, N.D.; Tabor, N.J. Quantitative paleoenvironmental and paleoclimatic reconstructions using paleosols. Earth-Sci. Rev. 2009, 95, 1-52.

7. Hasiotis, S.T. Continental ichnology: Fundamental processes and controls on trace fossil distribution. In Trace Fossils: Concepts, Problems, Prospects; Miller, W., III, Ed.; Elsevier: Amsterdam, The Netherlands, 2007; pp. 268-284.

8. Kraus, M.J.; Hasiotis, S.T. Significance of different modes of rhizoliths preservation to interpreting paleoenvironmental and paleohydrologic settings: Examples from Paleogene paleosols, Bighorn Basin, Wyoming, U.S.A. J. Sediment. Res. 2006, 76, 633-646.

9. Retallack, G.J. Soils of the Past, 2nd ed.; Blackwell Science: Oxford, UK, 2001.

10. Schaetzl, R.; Anderson, S. Soils: Genesis and Geomorphology; Cambridge University Press: Cambridge, UK, 2009. 
11. Kraus, M.J. Paleosols in clastic sedimentary rocks: Their geologic applications. Earth-Sci. Rev. 1999, $47,41-70$.

12. Greb, S.F.; Pashin, J.C.; Martino, R.L.; Eble, C.F.; Frank, T.D. Appalachian sedimentary cycles during the Pennsylvanian: Changing influences of sea level, climate, and tectonics. Geol. Soc. Am. Spec. Pap. 2008, 441, 235-248.

13. Scotese, C.R. Carboniferous paleocontinental reconstructions. In Predictive Stratigraphic Analysis-Concept and Application; Cecil, C.B., Edgar, N.T., Eds.; U.S. Government Printing Office: Washington, DC, USA, 1994; pp. 3-6.

14. Heckel, P.H. Glacial-eustatic base-level-Climatic model for Late Middle to Late Pennsylvanian coal-bed formation in the Appalachian Basin. J. Sediment. Res. 1995, 65B, 348-356.

15. Lebold, J.G.; Kammer, T.W. Gradient analysis of faunal distributions associated with rapid transgression and low accommodation space in a Late Pennsylvanian marine embayment: Biofacies of the Ames Member (Glenshaw Formation, Conemaugh Group) in the northern Appalachian Basin, USA. Palaeogeog. Palaeoclimatol. Palaeoecol. 2006, 231, 291-314.

16. Busch, R.M.; Rollins, H.B. Correlation of Carboniferous strata using a hierarchy of transgressive-regressive units. Geology 1984, 12, 471-474.

17. Ross, C.A.; Ross, J.R. Late Paleozoic sea levels and depositional sequences. In Timing and Depositional History of Eustatic Sequences: Constraints on Seismic Stratigraphy; Ross, C.A., Haman, D., Eds.; Cushman Foundation for Foraminiferal Research: Washington, DC, USA, 1987; Special Publication No. 24; pp. 137-149.

18. Heckel, P.H. Evaluation of evidence for glacio-eustatic control over marine Pennsylvanian cyclothems in North America and consideration of possible tectonic effects. SEPM Concepts Sedimentol. Paleontolog. 1994, 4, 65-87.

19. Cecil, C.B.; Dulong, F.T.; West, R.R.; Stamm, R.; Wardlaw, B.; Edgar, N.T. Climate controls on the stratigraphy of a Middle Pennsylvanian cyclothem in North America. SEPM Spec. Publ. 2003, 77, 151-182.

20. Nadon, G.C.; Kelly, R.R. The constraints of glacial eustasy and low accommodation on sequence-stratigraphic interpretations of Pennsylvanian strata, Conemaugh Group, Appalachian basin, U.S.A. Am. Assoc. Pet. Geol. Stud. Geol. 2004, 51, 29-44.

21. Donaldson, A.C.; Renton, J.J.; Presley, M.W. Pennsylvanian deposystems and paleoclimates of the Appalachians. Int. J. Coal Geol. 1985, 5, 167-193.

22. Sturgeon, M.T. The Geology and Mineral Resources of Athens County, Ohio; Ohio Division of Geological Survey: Columbus, OH, USA, 1958.

23. Martino, R.L. Sequence stratigraphy of the Glenshaw Formation (Middle-Late Pennsylvanian) in the central Appalachian basin. Am. Assoc. Pet. Geol. Stud. Geol. 2004, 51, 1-28.

24. Condit, D.D. The Conemaugh Formation in Southern Ohio. Ohio Nat. 1909, 9, 482-488.

25. Munsell Color. Munsell Rock Color Charts; Munsell Color: Baltimore, MD, USA, 2001.

26. Mack, G.H.; James, W.C.; Monger, H.C. Classification of paleosols. Geol. Soc. Am. Bull. 1993, 105, 129-136.

27. NRCS Soils. Keys to Soil Taxonomy, 11th ed.; USDA Natural Resources Conservation Service: Washington, DC, USA, 2010.

28. Brewer, R. Fabric and Mineral Analysis of Soils, 2nd ed.; Krieger: New York, NY, USA, 1976. 
29. Wilding, L.P.; Tessier, D. Genesis of Vertisols: Shrink-swell phenomena. In Vertisols: Their Distribution, Properties, Classification, and Management; Wilding, L.P., Puentes, R., Eds.; Texas A\&M University Printing Center: College Station, TX, USA, 1988; pp. 55-81.

30. Coulombe, C.E.; Wilding, L.P.; Dixon, J.B. Overview of Vertisols: Characteristics and impacts on society. Adv. Agron. 1996, 57, 289-375.

31. Jayawardane, N.S.; Greacen, E.L. The nature of swelling in soils. Austral. J. Soil Res. 1987, 25, 107-113.

32. Tabor, N.J.; Montañez, I.P.; Scotese, C.R.; Poulsen, C.J.; Mack, G.H. Paleosol archives of environmental and climatic history in paleotropical western Pangea during the latest Pennsylvanian through Early Permian. In Resolving the Late Paleozoic Ice Age in Time and Space; Frank, T.D., Isbell, J.L., Eds.; Geological Society of America: Boulder, CO, USA, 2008; pp. 291-304.

33. Bromley, R.G. Trace Fossils: Biology, Taphonomy and Applications, 2nd ed.; Chapman \& Hall: London, UK, 1996.

34. Gile, L.H.; Peterson, F.F.; Grossman, R.B. Morphological and genetic sequences of carbonate accumulation in desert soils. Soil Sci. 1966, 101, 347-360.

35. Salomons, W.; Goudie, A.; Mook, W.G. Isotopic composition of calcrete deposits from Europe, Africa, and India. Earth Surf. Proc. Landf. 1978, 3, 43-57.

36. Treadwell-Steitz, C.; McFadden, L.D. Influence of parent material and grain size on carbonate coatings in gravelly soils, Palo Duro Wash, New Mexico. Geoderma 2000, 94, 1-22.

37. Stiles, C.A.; Mora, C.I.; Driese, S.G.; Robinson, A.C. Distinguishing climate and time in the soil record: Mass-balance trends in Vertisols from the Texas coastal prairie. Geology 2003, 31, 331-334.

38. Kraus, M.J. Lower Eocene alluvial paleosols: Pedogenic development, stratigraphic relationships, and paleosol/landscape associations. Palaeogeog. Palaeoclimatol. Palaeoecol. 1997, 129, 387-406.

39. Birkeland, P.W. Soils and Geomorphology; Oxford University Press: New York, NY, USA, 1999.

40. Jenny, H. Factors of Soil Formation; McGraw-Hill: New York, NY, USA, 1941.

41. Mack, G.H.; James, W.C. Paleoclimate and the global distribution of paleosols. J. Geol. 1994, 102, 360-366.

42. Royer, D.L. Depth to pedogenic carbonate horizon as a paleoprecipitation indicator. Geology 1999, 27, 1123-1126.

43. Driese, S.G.; Ober, E.G. Paleopedologic and paleohydrologic records of precipitation seasonality from Early Pennsylvanian “underclay” paleosols, USA. J. Sediment. Res. 2005, 75, 997-1010.

(C) 2012 by the authors; licensee MDPI, Basel, Switzerland. This article is an open access article distributed under the terms and conditions of the Creative Commons Attribution license (http://creativecommons.org/licenses/by/3.0/). 